\title{
Non-destructive prediction of banana fruit quality using VIS/NIR spectroscopy
}

Manuela Zude*

Institute of Agricultural Engineering Bornim, Max-Eyth-Allee 100, 14469 Potsdam-Bornim, Germany

mzude@atb-potsdam.de

${ }^{*}$ Correspondence and reprints

Received 18 April 2002 Accepted 8 November 2002

Fruits, 2003, vol. 58, p. 135-142 (C) 2003 Cirad/EDP Sciences All rights reserved DOI: 10.1051/fruits:2003001

RESUMEN ESPAÑOL, p. 142

\section{Non-destructive prediction of banana fruit quality using VIS/NIR spectroscopy.}

Abstract - Introduction. During ripening, the pigment content, starch index and sugar content of banana fruit change, providing accurate indicators for maturity classification. However, at present, banana fruits are traded according to their color stage. This study is aimed at investigating a non-destructive, rapid instrumental method to measure fruit maturity and quality more precisely. Materials and methods. Musa cavendishii L. grown in Honduras were ripened in a commercial ripening chamber and selected at four different color stages. Visible (VIS) and near-infrared spectroscopy (NIRS) in reflectance mode were investigated for the non-destructive detection of fruit chlorophyll and sugar contents. Partial least squares regression was applied to auto-scaled spectral data. Reference analyses were performed using spectrophotometry after a diethyl ether extraction of chlorophyll and high performance liquid chromatography for individual sugar analysis. Results. Calibration models for spectral readings and laboratory destructive tests gave multivariate correlation coefficients of determination of $R^{2}>0.70$ for chlorophyll $a, R^{2}=0.96$ with standard errors of calibration $\left(s_{c a l}\right)$ of 1.6 , and standard errors of cross-validation $\left(s_{\text {cval }}\right)$ of 1.8 for glucose; $R^{2}=0.94$ with $s_{\text {cal }}$ of 0.8 , and $s_{\text {cval }}$ of 0.9 for sucrose; $R^{2}=0.96$ with $s_{\text {cval }}$ of 2.5 and $S_{\text {cval }}$ of 2.7 for fructose $\left(\mathrm{g} \cdot \mathrm{kg}^{-1}\right.$ on a dry weight basis). Conclusion. This paper shows the potential of VIS/NIRS for non-destructively predicting the maturity and quality of whole banana fruit based on determining fruit chlorophyll and sugar contents.

Germany / Musa (bananas) / measurement / maturity / infrared spectrophotometry / chlorophylls / sugars

\section{Prévision non destructive de la qualité de la banane par spectroscopie en lumière visible et proche infrarouge.}

Résumé - Introduction. Pendant la maturation, la teneur en pigment, l'index d'amidon et la teneur en sucres de la banane évoluent, fournissant des indicateurs précis pour évaluer la maturité du fruit. Cependant, actuellement, les bananes sont commercialisées en se basant sur leur coloration. Notre étude a cherché à étudier une méthode non destructive et rapide pour mesurer la maturité et la qualité de ce fruit avec plus de précision. Matériel et méthodes. Des fruits de Musa cavendishii L. produits en Honduras ont mûri dans une chambre de maturation commerciale, puis ils ont été triés en fonction de quatre colorations différentes. La spectroscopie en lumière visible (VIS) et proche infrarouge (NIR) en mode de réflectivité ont été utilisées pour la détection non destructive de la teneur en chlorophylle et en sucres des fruits. Une régression partielle des moindres carrés a été appliquée aux données automesurées du spectre. Des valeurs de référence ont été obtenues en utilisant la spectrophotométrie après une extraction de la chlorophylle à l'éther diéthylique et une chromatographie liquide à haute performance pour l'analyse individuelle des sucres. Résultats. Les modèles de calibrage pour la lecture du spectre et des mesures destructives de laboratoire couramment utilisées ont donné des coefficients de corrélation multivariables de détermination de $R^{2}>0,70$ pour la chlorophylle $a, R^{2}=0,96$ avec des erreurs standards de calibrage $\left(s_{c a l}\right)$ de 1,6 , et erreur standards de la contre-validation $\left(s_{\text {cval }}\right)$ de 1,8 pour le glucose, $R^{2}=0,94$ avec $s_{\text {cal }}=0,8$ et $s_{\text {cval }}=0,9$ pour le saccharose, $R^{2}=0,96$ avec $s_{\text {cal }}=2,5$ et $s_{\text {cval }}=2,7$ pour le fructose $\left(\mathrm{g} \cdot \mathrm{kg}^{-1}\right.$ sur une base de poids sec). Conclusion. Ces travaux montrent qu'il est possible de prévoir la maturité et la qualité du fruit entier de banane en utilisant les techniques non destructives de la spectroscopie en VIS/NIR basées sur la détermination des teneurs en chlorophylle et en sucres des fruits.

Allemagne / Musa (bananes) / mesure / maturité / spectroscopie infrarouge / chlorophylle / sucres 


\section{Introduction}

Banana is the world's largest fruit crop. The reducing sugar contents are prime quality parameters regarding consumer preferences, while the pigment content of the fruit skin visually indicates fruit maturity [1, 2]. However, measuring such fruit parameters wet-chemically is time-consuming. Therefore, color attributes are generally used to describe the produce within the distribution/market chain. The present study was conducted to assess the potential of non-destructive rapid spectral-optical readings in the visible (VIS) and near-infrared (NIR) wavelength range to analyze fruit pigment content and fruit sugar contents, respectively.

\subsection{VIS spectroscopy}

The chlorophylls and carotenoids content of the fruit skin and associated tissue provides the skin ground color of the fruit. During fruit maturity, a shift in the balance of chlorophyll breakdown and synthesis occurs [3], which gradually results in a decrease in the chlorophyll content in mature fruit $[4,5]$. This decrease in chlorophyll content may therefore be considered as an indicator of the banana fruit maturity [6]. Color cards, which match the banana fruit skin color at different maturity stages, are commonly used to obtain information on fruit maturity and related market quality. While this method is inexpensive and nondestructive, visual methods are influenced by subjective perception. However, chemical analyses performed in research are not applicable for rapid monitoring of single fruit. Therefore instrumental monitoring of fruit skin color could represent a possible tool for estimating maturity.

In recent years, it has been assumed that the fruit skin color, measured as the $\mathrm{a}^{*}$-value in a $\mathrm{L}^{*} \mathrm{a}^{*} \mathrm{~b}^{*}$ color model, might correlate with the chlorophyll content and could improve the fruit maturity determination [7]. This apparent suggestion has not been proven since color spaces only insufficiently describe pigment changes during fruit maturation. In remote sensing applica- tions, the chlorophyll red edge is successfully used to obtain information on the chlorophyll present in a leaf [8] and entire canopy. Precision farming commonly uses this chlorophyll red edge, which represents the long-wave inflection point of the chlorophyll absorption peak in the spectral reflectance recordings $[6,9]$. Following this suggestion, non-destructive chlorophyll prediction was achieved with high accuracy, when applied to apple fruit [10]. However, such measurements aimed at determining banana fruit maturity have not been described in the literature until now.

\subsection{NIR spectroscopy}

Wavelengths outside the visible spectrum have been used to measure the carbohydrate content of various agro-food products [11-15]. Absorption bands can be identified in the reflectance spectrum and their combination or overtones in the near-infrared (NIR) wavelength range. Unlike the absorption peaks of pigments in VIS caused by excitation of electrons, nearinfrared spectra show low intensity and broad bands due to overlapping vibrational modes. An assignment of peaks to individual molecule vibrations is normally not possible. Currently, wavelength or wholespectra analytical methods are being developed for the non-destructive determination of soluble solid content (SSC) and sugars. The SSC can be determined in intact fruit (apple, citrus, kiwi, mango, melon, onion, peach, potato and tomato) with a correlation coefficient of determination, $R^{2}=0.93$, and a standard error of calibration, $s_{c a l}=$ $0.5^{\circ}$ Brix [14-20]. Sugar contents of peeled banana fruits were predicted with $R^{2}=0.97$, $R^{2}=0.96, R^{2}=0.95$ and $s_{\text {cal }}=0.78 \%, s_{\text {cal }}=$ $0.21 \%, s_{\text {cal }}=0.16 \%$ for sucrose, glucose and fructose, respectively [21]. The author is not aware of published experiments dealing with non-destructive sugar analyses in banana fruit. Therefore, in the present study, sugar contents of banana pulp were measured using NIR spectroscopy referenced by pulp and skin sugar analyses by means of HPLC. 


\section{Materials and methods}

\subsection{Samples}

Cavendish banana fruit Musa cavendishii L. grown in Honduras were ripened in a commercial ripening chamber and visually selected at four different color stages. In the tests, the spectral reflectance in VIS/NIR range was measured first, then reference chemical methods were applied.

\subsection{Measurement of spectral reflectance}

The spectral reflectance of Cavendish banana fruit skin surfaces was measured by means of a UV-VIS-NIR spectrophotometer Type OMEGA 20 (Bruins Instruments, Puchheim, Germany), a scanning dualbeam instrument with a wavelength range from (220 to 2700) $\mathrm{nm}$. In the present study, monochromatic illumination in the wavelength range from (350 to 1700) nm was obtained by a monochromator connected to $\mathrm{a} \mathrm{D}_{2}$ and halogen lamp covering the range from 350 to $390 \mathrm{~nm}$ and from 390 to $1700 \mathrm{~nm}$, respectively. The measurements were carried out with slit width $0.5 \mathrm{~mm}$ by using an integrating sphere (diameter $100 \mathrm{~mm}$, white Spectralon coating) with geometry for diffuse reflectance. The fruits were placed with typical skin color at the aperture $(12 \mathrm{~mm} \times 15 \mathrm{~mm})$ of the integrating sphere. Data were recorded at wavelength steps of $1 \mathrm{~nm}$.

\subsection{Wet-chemical analysis}

Applying iodine potassium-iodide solution to half a sliced banana fruit and recognizing the appearing coloration of starch after 10 min monitored the starch degradation.

Sampling for analyzing chlorophyll and sugar contents was carried out on single banana fruits, measuring triplicates.

The chlorophyll $a$ content was analyzed by spectrophotometry after acetone/diethyl ether extraction [22, 23]. Chlorophyll absorbance in diethyl ether was recorded at $660.0 \mathrm{~nm}$ and $642.5 \mathrm{~nm}$ and chlorophyll $a$ content was calculated by subtracting the chlorophyll $b$ response using the specific extinction coefficients $\varepsilon=90.2$ and $\varepsilon=56.3$ for chlorophyll $a$ and $b$, respectively [23]. To eliminate errors due to evaporative losses from the volatile solutions, recordings were performed using a cuvette, which was immediately closed with a stopper. Chlorophyll concentration was recovered with at minimum $90 \%$.

Fruit sugar contents were analyzed via high-pressure liquid chromatography (HPLC). Samples were dried and ground. After protein degradation via Carrez-reagent and different dilution rates, the HPLC (Type LCD 202, GAT, Germany) was performed using the column Eurokat $\mathrm{H}(300 \mathrm{~mm} \times$ $8 \mathrm{~mm}, 10 \mu \mathrm{m})$ and the mobile phase $0.01 \mathrm{~N}$ $\mathrm{H}_{2} \mathrm{SO}_{4}$ at the rate of $0.8 \mathrm{~mL} \cdot \mathrm{min}^{-1}$ at $63 \mathrm{~Pa}$, and at $20^{\circ} \mathrm{C}$.

\subsection{Calibration and statistical analysis}

Auto-scaled data of spectra were calculated at each measured wavelength by subtracting the mean of the spectra divided by the standard deviation of the spectra. To process the visible spectra, the red edge was calculated by the second derivation $\left[R^{\prime \prime}(\lambda)=\right.$ $0]$. The partial least squares (PLS) calibration model was developed in Matlab 5.2.1 (Math Works, Inc., USA) with the routines of the PLS-Toolbox from Eigenvector (Eigenvector Research, Inc., USA). Particularly, the SIMPLS calibration model used here was built on linear regression between spectra and references while describing a large amount of the variation in the spectra and reference data (Handbook of Eigenvector Research, Inc., USA). Cross-validation was used to avoid overfitting of the model determining the amount of variation in the spectra and in the reference data covered by the model. Calibration statistics include the standard error of calibration $\left(s_{c a l}\right)$, the multivariate correlation coefficient of determination $\left(R^{2}\right)$, and the standard error of cross-validation $\left(s_{c v a l}\right)$. The optimal calibration was selected on the basis of minimizing the $s_{\text {cval }}$, which was calculated with the software internal leaveone-out method. 
Figure 1.

Banana slice appearance after an iodine potassium-iodide $\left(\mathrm{I}_{2} / \mathrm{KI}\right)$ solution was applied for $10 \mathrm{~min}$ to the fruit. Starch appeared as black coloration.
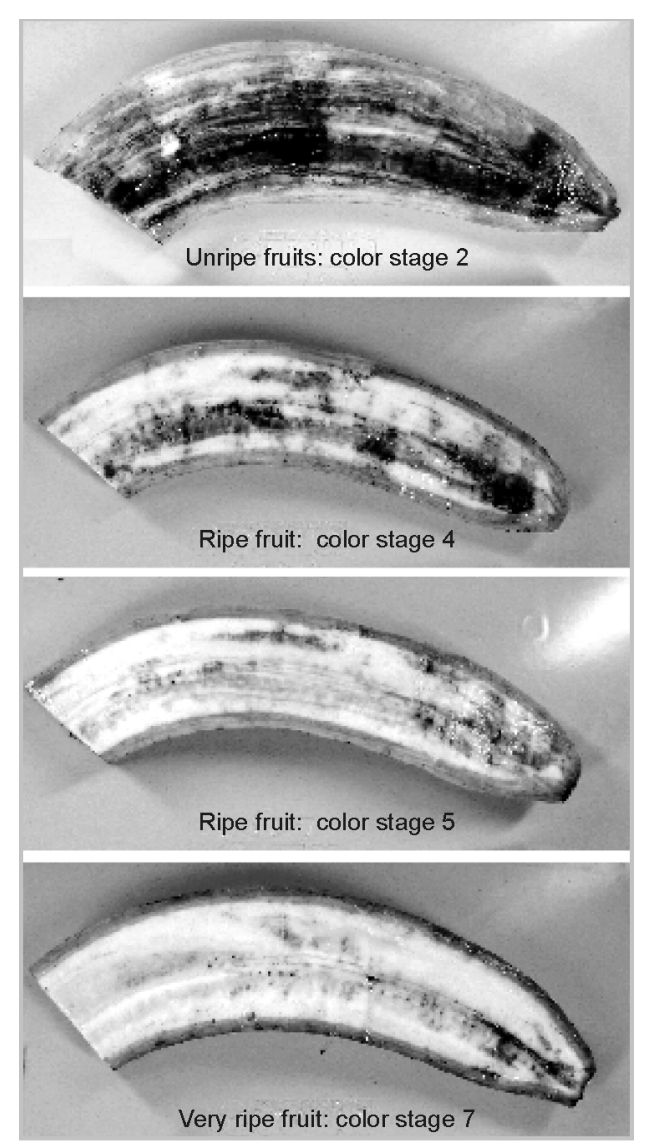

Figure 2.

Typical reflectance spectrum of a banana fruit measured without referring to a white standard. Data processing used in the present study is indicated at the relevant wavelength. Particularly, the red edge is marked, while loadings of partial leastsquare calibration are given for the prediction of fruit sugars.

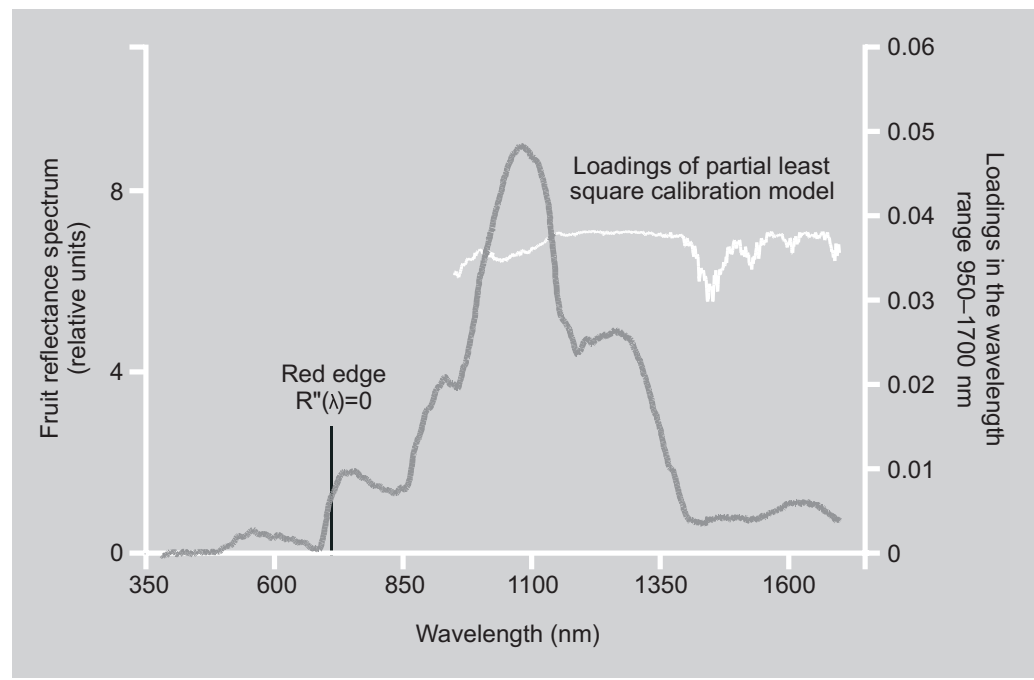

\section{Results and discussion}

\subsection{Fruit material}

Cavendish bananas were visually sorted by color stage with respect to the skin color. The whole range from dark green fruits to yellow fruits was covered. Experiments were carried out on unripe fruits (color stage 2), ripe fruits (color stages 4 and 5), representing fruits which are usually distributed, and very ripe fruits (color stage 7) which should be consumed.

Pictures were taken to show the fruit response to iodine potassium-iodide $\left(\mathrm{I}_{2} /\right.$ KI) solution, monitoring the different stages of starch hydrolysis in the pulp by black coloration of the starch-containing areas (figure 1). Fruit at an unripe stage shows extended black areas, indicating a low level of starch hydrolysis within the fruit, while almost no coloration was visible in "overripe" fruits.

\subsection{Measurement of spectral reflectance}

Looking at a typical banana fruit spectrum (figure 2), the visible region of the spectrum (VIS) shows an intensive absorption peak at $680 \mathrm{~nm}$. The fruit chlorophyll content can be determined by the so-called red edge, which represents the long-wave inflection point of the chlorophyll absorption peak [9]. In the near-infrared region of the spectrum (NIR), the absorption bands due to overtones of $\mathrm{OH}$ and $\mathrm{CH}$ groups are visible [18]. Fingerprints of specific overtone combinations can be interpreted by multivariate regression, e.g., by partial least squares (PLS) calibration models (figure 2).

\subsubsection{Visible region of the spectrum}

In the present study, the skin chlorophyll content decreased from unripe to ripe fruits. Mean values were $149.5 \mathrm{mg}$ chlorophyll $a \cdot \mathrm{m}^{-2}(s=19.5)$ for color stage 2 , $51.8 \mathrm{mg}$ chlorophyll $a \cdot \mathrm{m}^{-2}(s=25.6)$ for color stage $4,31.5 \mathrm{mg}$ chlorophyll $a \cdot \mathrm{m}^{-2}$ ( $s=12.3$ ) for color stage 5 and $3.9 \mathrm{mg}$ chlorophyll $a \cdot \mathrm{m}^{-2}(s=3.4)$ for color stage 7 . The 
chlorophyll content was also predicted by the red edge calculated $\left[\mathrm{R}^{\prime \prime}(\lambda)\right)=0$ ] from the visible spectra (figure 3). Using the second derivation instead of the first derivation [8] is advantageous due to accurately determining the $y^{\prime \prime}=0$ value that represents the wavelength of the long-wave inflection point of the chlorophyll absorption peak. Using the first derivative, the inflection point appears at the maximum value of the peak. This value can be calculated by the limited accuracy of an average, since the resolution of measuring points is not infinite. In the present study, non-destructive determining of chlorophyll was achieved with a $R^{2}=0.70$ with respect to the complete range of chlorophyll contents appearing in the measured banana fruit samples. The correlation coefficient was enhanced to $R^{2}=0.85$, taking into account exclusively the chlorophyll content range from (0 to 80) mg chlorophyll $a \cdot \mathrm{m}^{-2}$. The low resolution at high chlorophyll content resulted from the technical specification of the spectrometer system. Photons emitted by the light source are absorbed and reflected in the fruit tissue, generally leading to approximately $2 \%$ of the radiation recaptured as remittance by the spectrometer [24]. The sensor response in the chlorophyll absorption wavelength range was reduced to close to zero for unripe fruits due to high concentration of absorbing chlorophyll molecules.

The feasibility of using the red edge in non-destructive fruit maturity determination is encouraging regarding ripe and very ripe fruits, while fruits at low color stages were not distinguished due to the sensor limits (figure 4). However, improved results can be expected using a high intensity light source and spectrometer with enhanced light sensitivity increasing the ability to discriminate low radiation levels reflected from such unripe fruits. According to the common color stages within the distribution chain, encouraging potential seems to be available for discriminating fruits at color stage 4 from fruits at color stage 7 , recommended for consumption.

\subsubsection{Near-infrared region of the spectrum}

The fruit sugar contents of banana pulp measured by means of HPLC dramatically

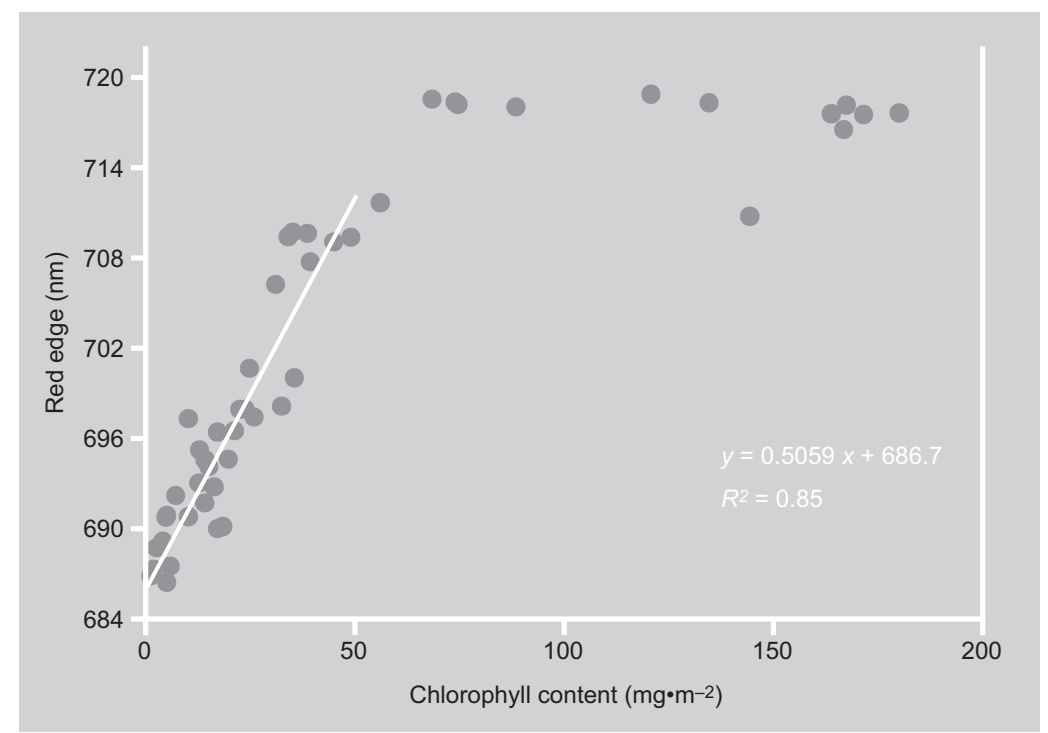

changed from color stage 2 to stage 4, Figure 3.

responding with the typical pattern of Correlation of skin chlorophyll banana fruits after ripening treatment $[1,2]$. content measured by wetSubsequently, after reaching color stage 5, fruits developed a marginal variation in sugar contents (figure 5). Individual sugar chemical analyses and VIS spectroscopy applied nondestructively to banana fruit. contents of the banana pulp samples covered the following ranges: $1.1-17.1 \mathrm{~g} \cdot \mathrm{kg}^{-1}$ on a dry weight basis for glucose, 1.2$23.2 \mathrm{~g} \cdot \mathrm{kg}^{-1}$ for sucrose and $0.7-20.3 \mathrm{~g} \cdot \mathrm{kg}^{-1}$ for fructose. Individual sugar contents of the banana skin samples covered the following ranges: $1.2-10.4 \mathrm{~g} \cdot \mathrm{kg}^{-1}$ for glucose, edge.

\section{Figure 4.}

Relation between the banana fruit color stage and the red

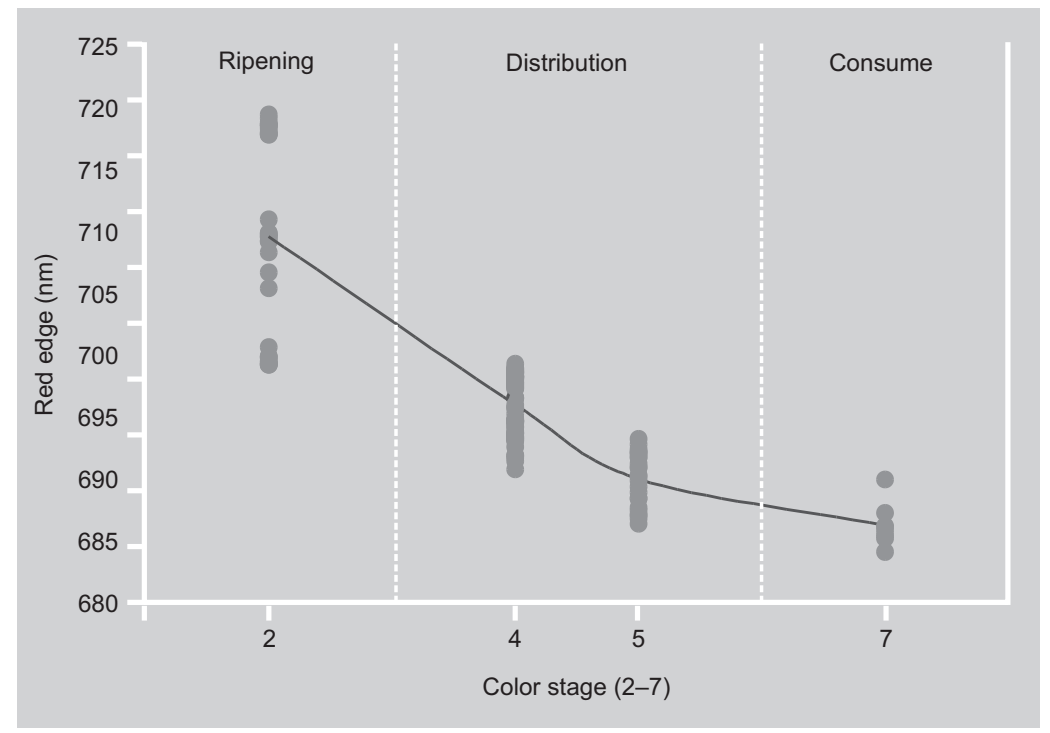




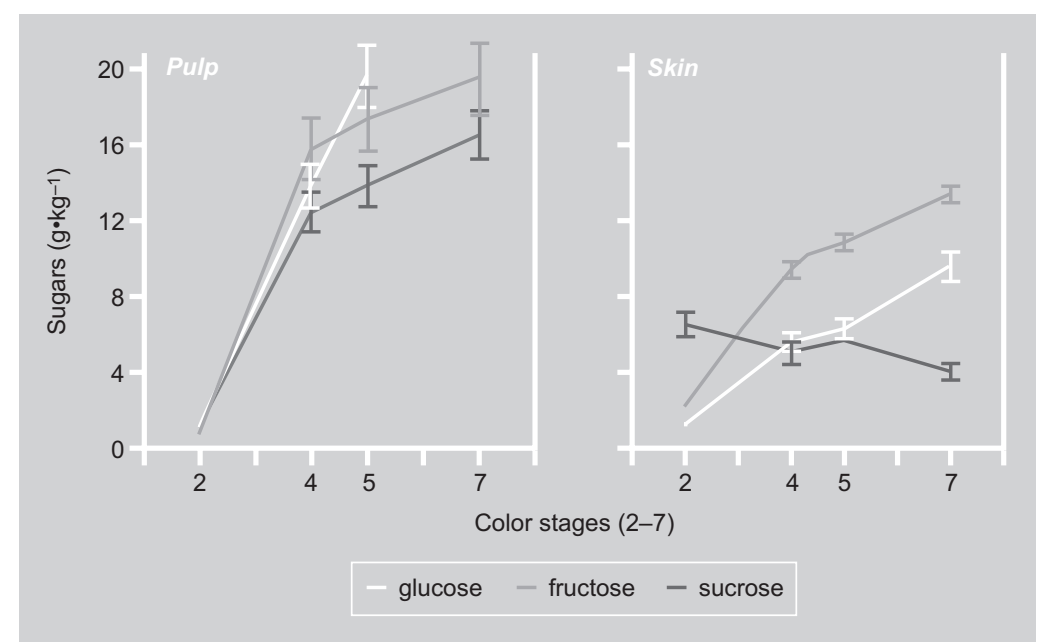

Figure 5.

Relation between the banana fruit color stage and the fruit sugar contents in pulp and skin.
Figure 6.

Correlation of banana sugar contents measured chemically as well as non-destructively by means of NIR spectroscopy.
3.9-7.4 g. kg-1 for sucrose and 2.2$14.5 \mathrm{~g} \cdot \mathrm{kg}^{-1}$ for fructose. The correlation coefficients of skin sugar contents and pulp sugar contents were $R^{2}=0.89$ for glucose, $R^{2}=0.41$ for sucrose and $R^{2}=0.96$ for fructose. Consequently, a non-destructive prediction of at least reducing sugars of banana skin by means of NIR spectroscopy would provide reasonable information on the internal banana maturity. However, it has to be kept in mind that sucrose contents in fruit skin and pulp are not well correlated (figure 5).

In the present study, it is assumed that pulp sugars were measured directly in the NIR spectra. Prediction of pulp sugars by means of the near-infrared spectra

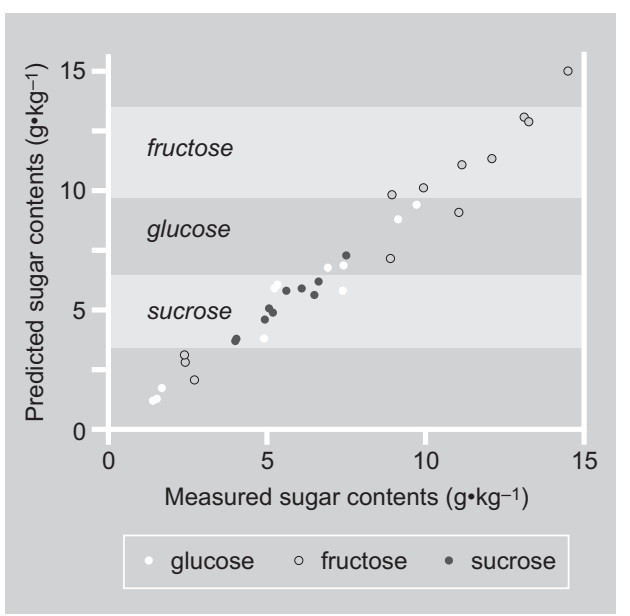

recorded non-destructively from unpeeled fruits showed high multivariate correlation coefficients of determination $R^{2}=0.96$ for glucose, $R^{2}=0.94$ for sucrose, $R^{2}=0.96$ for fructose (figure 0 ). Such accurate results indicate that NIR spectra responded directly to pulp sugars, since a measurement based on the sensor response to carbohydrates in the fruit skin would have caused a low correlation coefficient for sucrose. Thus, NIR spectroscopy applied non-destructively to banana fruit provides valuable information on internal fruit maturity and fruit quality.

Standard errors of calibration $\left(s_{c a l}\right)$ and cross-validation $\left(s_{\text {cval }}\right)$ were calculated on a partial least squares model using a small number of six latent variables: $1.6\left(s_{\text {cval }}=\right.$ $1.8)$ for glucose, $0.8\left(s_{\text {cval }}=0.9\right)$ for sucrose and $2.5\left(s_{\text {cval }}=2.7\right)$ for fructose $\left(\mathrm{g} \cdot \mathrm{kg}^{-1}\right.$ on a dry weight basis). The loadings of the model (figure 2) prove a reasonable curvature with respect to the known absorption bands caused by overtones of carbohydrates [18].

\section{Conclusions}

The feasibility of non-destructive spectroscopy in the visible wavelength range for predicting the chlorophyll content of banana fruit in the market was shown. Internal fruit sugar contents were predicted with high accuracy using the near-infrared region of the spectrum wavelength range. The potential of spectral analyses for nondestructively monitoring fruit maturity and fruit quality was demonstrated.

\section{References}

[1] Marriott J., Bananas-physiology and biochemistry of storage and ripening for optimum quality, CRC Cr. Rev. Food Sci. 13 (1980) 41-88.

[2] Mustaffa R., Osman A., Yusof S., Mohamed S., Physico-chemical changes in Cavendish banana (Musa cavendishii L. var. Montel) at different positions within a bunch during development and maturation, J. Sci. Food Agric. 78 (1998) 201-207. 
[3] Matile P., Hötensteiner S., Thomas H., Chlorophyll degradation, Annu. Rev. Plant Phys. 50 (1999) 67-95.

[4] Jacob-Wilk D., Holland D., Goldschmidt E.E., Riov J., Eyal Y., Chlorophyll breakdown by chlorophyllase: isolation and functional expression of the Chlase1 gene from ethylene-treated citrus fruit and its regulation during development, Plant J. 20 (1999) 653661.

[5] Olsen K.L., Schomer H.A., Bartram R.D., Segregation of 'Golden Delicious' apples for quality by light transmission, Am. Soc. Hortic. Sci. (1969) 821-828.

[6] Merzlyak M.N., Gitelson A.A., Chivkunova O.B., Rakitin V.Y., Non-destructive optical detection of pigment changes during leaf senescence and fruit ripening, Physiol. Plantarum 106 (1999) 135-141.

[7] De Jager A., Roelofs F.M.M., Prediction of optimum harvest date of Jonagold, in: De Jager A., Johnson D., Höhn E., The postharvest treatment of fruit and vegetables Current status and future prospects, Proceedings of the Sixth International Symposium of the European Concerted Action Program, COST, Luxembourg, 94, 1996, pp. 21-31.

[8] Gitelson A.A., Merzlyak M.N., Lichtenthaler H.K., Detection of red edge position and chlorophyll content by reflectance measurements near $700 \mathrm{~nm}$, J. Plant Physiol. 148 (1996) 501-508.

[9] Lichtenthaler H.K., Gitelson A., Lang M., Non-destructive determination of chlorophyll content of leaves of a green and an aurea mutant of tobacco by reflectance measurements, J. Plant Physiol. 148 (1996) 483-493.

[10] Zude-Sasse M., Truppel I., Herold B., An approach to non-destructive apple chlorophyll determination, Postharvest Biol. Tec. 25 (2002) 123-133.

[11] Bellon V., Vigneau J.L., Leclercq M., Feasibility and performances of a new, multiplexed, fast and low-cost fiber-optic NIR spectrometer for on-line measurement of sugar in fruits, Appl. Spectrosc. 47 (1993) 10791083.

[12] Davenel A., Crochon M., Pourcin J., Verlaque P., de Vaux M.C., On line infrared measurement in food processing, AgEng (1988) 88308.
[13] Dull G.G., Birth G.S., Leffler R.G., Use of near infrared analysis for nondestructive measurements of dry matter in potatoes, Am. Potato J. 66 (1989) 215-225.

[14] Huxol C.C., Bolin H.R., Mackey B.E., Near infrared analysis potential for grading raisin quality and moisture, J. Food Sci. 60 (1995) 176-180.

[15] Kawano S., Non destructive NIR quality evaluation of fruits and vegetables in Japan, NIR News 5 (1994) 10-12.

[16] Birth G.S., Non destructive quality evaluation of agricultural products. Introduction, J. Food Protect. 41 (1978) 48-49.

[17] Cael J.J., Koening J.L., Blackwell J., Infrared and Raman spectroscopy of carbohydrate, Carbohydr. Res. 32 (1974) 79-91.

[18] Murray I., Williams P.C., Chemical principles of near-infrared technology, in: Williams $P$., Norris K. (Eds.), Near-infrared technology in the agriculture and food industries, ASCC, Inc., St. Paul, Minnesota, USA, 1987, pp. 17-34.

[19] Lammertyn J., Nicola B., Ooms K., De Smedt V., De Baerdemaeker J., Nondestructive measurement of acidity, soluble solids, and firmness of Jonagold apples using NIR-spectroscopy, Trans. ASAE 41 (1998) 1089-1094.

[20] Slaughter D.C., Nondestructive determination of internal quality in peaches and nectarines, Trans. ASAE 38 (1995) 617-623.

[21] Tarkosova J., Copikova J., Determination of carbohydrate content in bananas during ripening and storage by near infrared spectroscopy, J. Near Infrared Spec. 8 (2000) 21-26.

[22] Holden M., Chlorophylls, in: Goodwin T.W. (Ed.), Chemistry and biochemistry of plant pigments, vol. 2, Acad. Press London-New York-San Francisco, UK, 1976.

[23] Porra R.J., Thompson W.A., Kriedemann P.E., Determination of accurate extinction coefficients and simultaneous equations for assaying chlorophylls $a$ and $b$ extracted with four different solvents: verification of the concentration of chlorophyll standards by atomic absorption spectroscopy, Biochim. Biophys. Acta 975 (1989) 384-394.

[24] Birth G.S., How light interacts with foods, in: Gafney J. Jr. (Ed.), Quality Detection in Foods, ASAE, St. Joseph, USA, 1976, pp. 6-11. 


\section{Previsión no destructiva de la calidad del banano mediante espectroscopia de luz visible e infrarrojo cercano.}

Resumen - Introducción. Durante la maduración, el contenido en pigmento, el índice de almidón y el contenido de azúcares del banano evolucionan, proporcionando indicadores precisos para evaluar la madurez del fruto. Sin embargo, los bananos se comercializan actualmente basándose en su coloración. Nuestro trabajo tuvo como objetivo el estudio de un método no destructivo y rápido para medir la calidad de este fruto con mayor precisión. Material y métodos. Unos bananos de Musa cavendishii L., producidos en Honduras, maduraron en cámara de maduración comercial y, posteriormente, fueron seleccionados según cuatro grados de coloración diferentes. La espectroscopia de luz visible (VIS) y de infrarrojo cercano (NIR) en modo de reflectividad, fueron estudiadas para la detección no destructiva del contenido de clorofila y azúcares de los frutos. Se aplicó una regresión parcial de los mínimos cuadrados a los datos automedidos del espectro. Se obtuvieron valores de referencia empleando la espectrometría, tras extracción de la clorofila con éter dietílico, y una cromatografía líquida de alto rendimiento para el análisis individual de los azúcares. Resultados. Los modelos de calibrado para la lectura del espectro y de las medidas destructivas de laboratorio normalmente empleadas, proporcionaron coeficientes de correlación multivariables de determinación de $R^{2}>0,70$ para la clorofila $a, R^{2}=0,96$ con errores estándar de calibrado $\left(s_{c a l}\right)$ de 1,6 , y error estándar de la contravalidación $\left(s_{\text {cval }}\right)$ de 1,8 para la glucosa, $R^{2}=0,94$ con $s_{\text {cal }}=$ 0,8 y $s_{\text {cval }}=0,9$ para la sacarosa, $R^{2}=0,96$ con $s_{\text {cal }}=2,5$ y $s_{\text {cval }}=2,7$ para la fructosa $\left(\mathrm{g} \cdot \mathrm{kg}^{-1}\right.$ sobre una base de peso seco). Conclusión. Estos trabajos muestran que es posible prever la madurez y la calidad del fruto entero de banano mediante las técnicas no destructivas de espectroscopia VIS/NIR basadas en la determinación de los contenidos de clorofila y azúcares de los frutos.

Alemania / Musa (bananos) / medición / madurez / espectroscopia infrarroja / clorofilas / azucares

To access this journal online: www.edpsciences.org 